University of Nebraska - Lincoln

DigitalCommons@University of Nebraska - Lincoln

Faculty Papers and Publications in Animal

Science

Animal Science Department

November 2004

\title{
National Pork Producers Council Maternal Line Genetic \\ Evaluation: A comparison of growth and carcass traits in terminal progeny
}

\author{
J. P. Cassidy \\ North Carolina State University, Raleigh \\ O. W. Robison \\ North Carolina State University, Raleigh \\ R. K. Johnson \\ University of Nebraska-Lincoln, rjohnson5@unl.edu \\ J. W. Mabry \\ lowa State University \\ L. L. Christian \\ lowa State University \\ See next page for additional authors \\ Follow this and additional works at: https://digitalcommons.unl.edu/animalscifacpub \\ Part of the Animal Sciences Commons
}

Cassidy, J. P.; Robison, O. W.; Johnson, R. K.; Mabry, J. W.; Christian, L. L.; Tokach, M. D.; Miller, R. K.; and Goodwin, R. N., "National Pork Producers Council Maternal Line Genetic Evaluation: A comparison of growth and carcass traits in terminal progeny" (2004). Faculty Papers and Publications in Animal Science. 63.

https://digitalcommons.unl.edu/animalscifacpub/63

This Article is brought to you for free and open access by the Animal Science Department at DigitalCommons@University of Nebraska - Lincoln. It has been accepted for inclusion in Faculty Papers and Publications in Animal Science by an authorized administrator of DigitalCommons@University of Nebraska - Lincoln. 


\section{Authors}

J. P. Cassidy, O. W. Robison, R. K. Johnson, J. W. Mabry, L. L. Christian, M. D. Tokach, R. K. Miller, and R. N. Goodwin 


\title{
National Pork Producers Council Maternal Line Genetic Evaluation: A comparison of growth and carcass traits in terminal progeny ${ }^{1}$
}

\author{
J. P. Cassady*2, O. W. Robison*, R. K. Johnson†, J. W. Mabry $\neq$, L. L. Christian \\ M. D. Tokach\$, R. K. Miller II, and R. N. Goodwin\#
}

*Department of Animal Science, North Carolina State University, Raleigh 27695; †Department of Animal Sciences, University of Nebraska, Lincoln 68583; $\$$ Department of Animal Sciences, Iowa State University, Ames 50011; §Department of Animal Sciences and Industry, Kansas State University, Manhattan 66506;

IDepartment of Animal Sciences, Texas A\&M University, College Station 77843; and

\#National Pork Board, Clive, IA 50325

\begin{abstract}
The objective of this study was to compare growth and carcass traits of 1,252 progeny of six commercially available dam lines included in the $\mathrm{Na}$ tional Pork Producers Council Maternal Line Evaluation Project. Lines compared included one maternal line supplied by each of American Diamond Swine Genetics (ADSG), Danbred NA (DB), two lines supplied by Monsanto Choice Genetics (DK and GPK347), Newsham Hybrids $(\mathrm{NH})$, and Landrace $\times$ Large White females supplied by the National Swine Registry (NSR). All females were mated to DB, Duroc-Hampshire terminal sires. Traits analyzed were ADG from 56 to $115 \mathrm{~kg}$ live weight, days to $115 \mathrm{~kg}$, backfat thickness measured at the 10th rib, carcass length, dressing percent, and 10thrib LM area. Carcass traits were adjusted to a carcass weight of $85 \mathrm{~kg}$. The statistical model included fixed effects of maternal line, sex, farrowing group, and finishing unit (farm). All two-way interactions among main effects were tested and removed from final models because they were not significant. In addition, because they were not significant, effects of farm and farrowing group were removed from models for carcass length and
\end{abstract}

10th-rib backfat thickness, and farm was removed from the model for LM area. Least squares means for ADG ranged from 0.74 to $0.79 \mathrm{~kg} / \mathrm{d}$. The GPK347 line had lower ADG and greater days to $115 \mathrm{~kg}$ than all other lines $(P<0.05)$. The ADSG $(P<0.05)$ and NH $(P<0.01)$ progeny had lower ADG than DK progeny. The DK line had the fewest days to $115 \mathrm{~kg}(P<0.05)$. Progeny for the DB and NH lines had the least 10th-rib backfat, differing from ADSG, DK, and GPK347 $(P<0.05)$. Pigs from DB females had the greatest dressing percent, differing from ADSG, DK, GPK347, and NH $(P<0.05)$. The GPK347 had a lower dressing percent than all other lines $(P<0.05)$. Progeny of DB females had the greatest LM area, differing from ADSG, DK, GPK347, and NSR $(P<0.05)$. Offspring from ADSG and GPK347 had the smallest LM area; however, GPK347 and NSR did not differ. Differences in carcass length were statistically significant; however, actual differences were small. Economic weights for these traits relative to reproductive traits must be considered in integrated economic analyses to properly compare differences among lines in net economic value for specific markets.

Key Words: Carcass, Growth, Line Evaluation, Pigs

(c2004 American Society of Animal Science. All rights reserved.

J. Anim. Sci. 2004. 82:3482-3485

\section{Introduction}

Much research was done in the 1970s and 1980s comparing breeds of pigs for reproduction, growth, and carcass traits (Wilson and Johnson, 1981; Kuhlers et al.,

\footnotetext{
${ }^{1}$ Funding for the project was provided through check-off dollars of the National Pork Board and administered by the National Pork Producers Council.

${ }^{2}$ Correspondence: 232B Polk Hall (phone: 919-359-0503; fax 919515-7780; e-mail: joe_cassady@ncsu.edu).

Received June 23, 2004.

Accepted September 21, 2004.
}

1985; McLaren et al., 1987). Modeling studies (Bennett et al., 1983) have demonstrated the importance of growth and carcass traits in maternal lines on costs of pork production. Since then, breeding organizations have implemented terminal crossbreeding systems with specialized sire and dam lines. In 1996, the U.S. National Pork Producers Council initiated a Maternal Line Evaluation Project (MLP) to test differences in maternal line performance and effects of maternal line genetics on market pig performance. The project was conducted to meet a need, expressed by commercial producers, for an objective evaluation of lifetime productivity of commercially available maternal lines. Ma- 
ternal lines and progeny of maternal lines, which were commercially available in 1996 and 1997, were compared. The objective of this paper was to estimate differences among maternal lines for growth and carcass traits of their progeny.

\section{Materials and Methods}

\section{Description of Genetic Lines}

All females were crossbred with Large White/Yorkshire and Landrace being the predominant breed composition. Four commercial companies, American Diamond Swine Genetics (ADSG; Prairie City, IA), Danbred North American (DB; Seward, NE), Monsanto Choice Genetics (DK; St Louis, MO), and Newsham Hybrids (NH; Colorado Springs, CO) entered their maternal lines for evaluation. Monsanto Choice Genetics also entered a second line (GPK347), which was a cross between a Monsanto maternal line and a line developed at the University of Nebraska (Johnson et al., 1999). Females from the DK and GPK347 lines had 25\% common genetic background (D. Fox, Monsanto Choice Genetics; personal communication). The National Swine Registry (NSR; West Lafayette, IN), representing independent seed stock producers, entered Landrace $\times$ Large White and Large White $\times$ Landrace females.

\section{Population Structure and Management}

A total of 3,599 gilts, 567 to 631 per line, were entered at 7 to $20 \mathrm{~d}$ of age, and lifetime productivity from 165 $\mathrm{d}$ of age through four parities was evaluated. A detailed description of the experimental design is in Moeller et al. (2004). At entry, gilts were placed in wean-to-finish barns, and then moved to sow units at approximately $165 \mathrm{~d}$ of age. Culling of gilts in the wean-to-finish barns was only for extremely low weight gain (weights more than three standard deviations below the mean), health, or death, and culling in sow units was limited to chronic illness, injury, reproductive failure, or death.

All gilts were checked for estrus daily starting on arrival at the sow unit. Gilts were not bred at first observed estrus. Beginning with their second observed estrus, gilts were inseminated with pooled semen from DB Duroc-Hampshire sires $12 \mathrm{~h}$ after initial detection of estrus and every $24 \mathrm{~h}$ thereafter while in standing heat. Subsequently, sows were bred at their first observed postweaning estrus and culled if they failed to express estrus within $50 \mathrm{~d}$ of weaning or if they were detected not pregnant at $50 \mathrm{~d}$ after breeding. There were 2,592 females that produced at least one litter.

Pigs were born in three farrowing groups and the age difference within farrowing group was $40 \mathrm{~d}$ or less. A barrow or gilt was selected randomly at weaning from either the first, second, or third parity litter to evaluate progeny performance. No more than one pig was sampled from any female. The number of females sampled
Table 1. Number of observations and least squares means for live weight at slaughter and carcass weight

\begin{tabular}{lcccc}
\hline \hline Line or sex & No. & $\begin{array}{c}\text { On-test } \\
\text { weight, } \\
\mathrm{kg}\end{array}$ & $\begin{array}{c}\text { Off-test } \\
\text { weight, } \\
\mathrm{kg}\end{array}$ & $\begin{array}{c}\text { Carcass } \\
\text { weight, } \\
\mathrm{kg}\end{array}$ \\
\hline Maternal line & & & & \\
ADSG & & & 115 & 86 \\
DB & 206 & 57 & 115 & 87 \\
DK & 165 & 55 & 116 & 87 \\
GPK347 & 193 & 56 & 114 & 84 \\
NH & 290 & 57 & 114 & 85 \\
NSR & 219 & 55 & 115 & 86 \\
Sex & 179 & 56 & & \\
Barrow & & & 116 & 86 \\
Gilt & 629 & 56 & 114 & 85 \\
\hline
\end{tabular}

${ }^{\mathrm{a}} \mathrm{ADSG}=$ American Diamond Swine Genetics (Prairie City, IA), DB = Danbred USA (Seward, NE), DK = Monsanto Choice Genetics DK44 (St. Louis, MO), GPK347 = Monsanto Choice Genetics GPK347, $\mathrm{NH}=$ Newsham Hybrids (Colorado Springs, CO), and NSR = National Swine Registry (West Lafayette, IN; Landrace $\times$ Large White).

per line is reported in Table 1 . A segregated early weaning program developed for the National Pork Producers Council Terminal Line National Genetic Evaluation Program was followed (Baas et al., 2003). Pigs were weaned between 10 and $21 \mathrm{~d}$ of age and moved to the Minnesota Swine Testing Station in New Ulm. The average weight of pigs entering the nursery was $4.7 \pm 1$ kg. Pigs were injected with Ivomec (Merial, Duluth, GA) upon arrival and with Naxcel (Pfizer Animal Health, New York, NY) on d 1 and 2. Mycoplasma vaccination occurred on d 7 and 21, and PRRS vaccination occurred on d 14. Pigs were not penned by maternal line but were penned separately by sex. A pen of pigs was put on test when the average weight of pigs in the pen reached $60 \mathrm{~kg}$. Pigs were individually weighed off test each week and transported $161 \mathrm{~km}$ to the Quality Pork Processors plant in Austin, MN. Average on-test weight was $59 \pm 14 \mathrm{~kg}$, and pigs were slaughtered at an average live weight of $115 \pm 6 \mathrm{~kg}$. Days on test averaged $75 \pm 17 \mathrm{~d}$. Carcass traits were measured at the Quality Pork Processors plant. Traits recorded were ADG, days to $115 \mathrm{~kg}$ (D115), live weight at slaughter, carcass weight, carcass length (LEN), 10th-rib LM area (LMA), and backfat thickness (BF) approximately $5 \mathrm{~cm}$ off the midline at the 10th rib of a ribbed, chilled carcass. Dressing percent (DR) was calculated by dividing carcass weight by live weight at the time of slaughter.

\section{Statistical Analyses}

Carcass length, LMA, and BF were adjusted to an 85-kg carcass weight before the final statistical analysis. The GLM procedure of SAS (SAS Inst., Inc., Cary, $\mathrm{NC}$ ) was used to obtain and test solutions of linear and quadratic coefficients for each maternal line and sex. Quadratic regression coefficients were not significant for any trait and were dropped from the adjustment equations. Linear regression coefficients for LEN and $\mathrm{BF}$ were independent of sex and line; thus, one adjust- 
Table 2. Probability values for fixed effects included in the model for each trait

\begin{tabular}{lcccc}
\hline \hline Trait $^{\mathrm{a}}$ & $\begin{array}{c}\text { Maternal } \\
\text { line }\end{array}$ & Sex & $\begin{array}{c}\text { Farrowing } \\
\text { group }\end{array}$ & Farm \\
\hline ADG, kg & 0.001 & 0.001 & 0.001 & 0.04 \\
$\mathrm{BF}, \mathrm{cm}$ & 0.001 & 0.001 & - & - \\
D115 & 0.001 & 0.001 & 0.001 & 0.09 \\
DR & 0.001 & 0.001 & 0.001 & 0.03 \\
LEN & 0.001 & 0.001 & - & - \\
LMA & 0.001 & 0.001 & 0.001 & - \\
\hline
\end{tabular}

${ }^{\mathrm{a}} \mathrm{BF}=$ backfat measured at the 10th rib, $5 \mathrm{~cm}$ off the mid-line of a chilled, ribbed carcass, D115 = days to $115 \mathrm{~kg}, \mathrm{DR}=$ dressing percent, LEN = carcass length, and LMA $=10$ th-rib LM area.

ment equation was used for all pigs. The adjustment for BF and LEN used the following general equation: $\hat{T}=T-b(W t-85)$, where $T$ represents the trait, $b$ represents the estimated linear regression coefficient, and $W t$ is the weight of animal in kilograms at the time of measurement. Interactions between line and sex existed for LMA linear regressions $(P<0.05)$. The adjustment for LMA used the following general equation: $L \hat{M} A_{i j}=L M A_{i j}-b_{i}\left(W t_{i j}-85\right)$, where $L M A$ represents the trait, $j$ represents the $j$ th pig in line/sex subclass $i, b$ represents the estimated linear regression coefficient, and $W t$ is the weight of animal at the time of measurement.

Traits were analyzed with a fixed model including effects of sex $(n=2)$, maternal line $(n=6)$, farrowing group ( $\mathrm{n}=3$ ), finishing unit (farm, $\mathrm{n}=2$ ), and all two-way interactions using the GLM procedure of SAS. None of the two-way interactions was significant, so they were removed from final models. Farm was not significant and was removed from models for LEN, LMA, and BF (Table 2). Farrowing group was not significant and was removed from the model for $\mathrm{BF}$ and LEN (Table 2). Relationships among individuals were not considered in the analysis. The sampling procedure for the MLP was designed to minimize relationships among dams within maternal line. Pooled semen was used for mating MLP females. Therefore, sire was unknown and pigs from a common litter would be expected to be a mixture of full- and half-sibs. In addition, the present study included sampling of no more than one pig from one dam. Due to these factors, relationships among progeny tested were assumed to be small and were not expected to affect tests among line means. Single-df contrasts between all possible combinations of maternal line least squares means, resulting in 15 contrasts per trait, were used to compare maternal line means. A difference among least squares means is an estimate of half the additive genetic plus all the maternal difference among maternal lines. A Tukey-Kramer adjustment (Hayter, 1984) was used to account for multiple testing within trait. The Tukey-Kramer adjustment used to test the difference between two means is $\bar{y}_{i}-\bar{y}_{j} / s \sqrt{\left(1 / n_{i}+1 / n_{j}\right) / 2} \geq q(\alpha ; k, v)$, where $q(a, k, v)$ is the
Table 3. Least squares means and standard errors for growth traits for maternal lines and sexes

\begin{tabular}{llc}
\hline \hline & \multicolumn{2}{c}{ Traits } \\
\cline { 2 - 3 } Line or sex & ADG, kg/d & Days to $115 \mathrm{~kg}$ \\
\hline Maternal line & \\
ADSG & $0.77^{\mathrm{y}}$ & $175^{\mathrm{y}}$ \\
DB & $0.77^{\mathrm{xy}}$ & $176^{\mathrm{y}}$ \\
DK & $0.79^{\mathrm{x}}$ & $172^{\mathrm{x}}$ \\
GPK347 & $0.74^{\mathrm{z}}$ & $182^{\mathrm{z}}$ \\
NH & $0.76^{\mathrm{y}}$ & $179^{\mathrm{yz}}$ \\
NSR & $0.78^{\mathrm{xy}}$ & $177^{\mathrm{yz}}$ \\
SED & 0.011 & 1.8 \\
Sex & & \\
Barrow & $0.81^{\mathrm{x}}$ & $175^{\mathrm{x}}$ \\
Gilt & $0.78^{\mathrm{y}}$ & $179^{\mathrm{y}}$ \\
SED $^{\mathrm{b}}$ & 0.01 & 0.8 \\
\hline
\end{tabular}

aDifferences among least squares means estimate half the additive genetic plus all the maternal effect. $\mathrm{ADSG}=$ American Diamond Swine Genetics (Prairie City, IA), DB = Danbred USA (Seward, NE), DK $=$ Monsanto Choice Genetics DK44 (St. Louis, MO), GPK347 = Monsanto Choice Genetics GPK347, NH = Newsham Hybrids (Colorado Springs, CO), and NSR = National Swine Registry (West Lafayette, IN; Landrace $\times$ Large White).

${ }^{\mathrm{b}} \mathrm{SED}=$ standard error of the difference among least-squares means using a Tukey-Kramer adjustment for multiple testing.

$x, y, z$ Means among maternal lines or between sexes, within columns, that do not have a common superscript differ, $P<0.05$.

$\alpha$-level critical value of a studentized range distribution of $k$ independent random variables with $\nu$ degrees of freedom. No attempt was made to adjust for multiple testing across traits. The number of observations and least squares means for slaughter weight and carcass weight are given in Table 1.

\section{Results}

For the purpose of results and discussion, line designations will refer to progeny performance. Least squares means and standard errors for growth traits and carcass traits are presented in Tables 3 and 4, respectively. Barrows had greater ADG, more backfat, shorter carcasses, fewer D115, lower DR, and smaller LMA than gilts $(P<0.001)$. Maternal line effects were significant for all traits. Least squares means for ADG ranged from 0.74 to $0.79 \mathrm{~kg} / \mathrm{d}$. The GPK347 line had lower ADG and greater D115 than all other lines $(P<$ $0.05)$. The ADSG $(P<0.05)$ and NH $(P<0.01)$ progeny had lower ADG than DK progeny. The DK line had the fewest D115 $(P<0.05)$. Progeny for the DB and NH lines had the least BF, differing from ADSG, DK, and GPK347 $(P<0.05)$. Pigs from DB females had the greatest DR, differing from ADSG, DK, GPK347, and NH ( $P$ $<0.05$ ). The GPK347 had a lower DR than all other lines $(P<0.05)$. Progeny of DB females had the greatest LMA, differing from ADSG, DK, GPK347, and NSR ( $P$ $<0.05$ ). Offspring from ADSG and GPK347 had the smallest LMA; however, GPK347 and NSR did not differ. Differences in LEN were statistically significant; however, actual differences were small. 
Table 4. Least squares means and standard errors for carcass traits for maternal lines and sexes

\begin{tabular}{llccc}
\hline \hline & \multicolumn{4}{c}{ Traits $^{\mathrm{a}}$} \\
\cline { 2 - 5 } Line or sex & $\mathrm{BF}, \mathrm{cm}$ & $\mathrm{DR}, \%$ & LEN, cm & LMA, cm \\
\hline Maternal line & \\
ADSG & $2.4^{\mathrm{x}}$ & $74.5^{\mathrm{y}}$ & $83.0^{\mathrm{x}}$ & $41.3^{\mathrm{z}}$ \\
DB & $2.0^{\mathrm{z}}$ & $75.2^{\mathrm{x}}$ & $82.4^{\mathrm{xz}}$ & $45.2^{\mathrm{w}}$ \\
DK & $2.3^{\mathrm{xy}}$ & $74.6^{\mathrm{y}}$ & $82.3^{\mathrm{z}}$ & $43.3^{\mathrm{x}}$ \\
GPK347 & $2.3^{\mathrm{xy}}$ & $74.2^{\mathrm{z}}$ & $82.8^{\mathrm{x}}$ & $41.5^{\mathrm{yz}}$ \\
NH & $2.0^{\mathrm{z}}$ & $74.6^{\mathrm{y}}$ & $82.7^{\mathrm{x}}$ & $44.1^{\mathrm{wx}}$ \\
NSR & $2.2^{\mathrm{yz}}$ & $74.8^{\mathrm{xy}}$ & $82.3^{\mathrm{z}}$ & $42.9^{\mathrm{xy}}$ \\
SED & 0.06 & 0.2 & 0.2 & 0.5 \\
Sex & & & & \\
Barrow & $2.4^{\mathrm{x}}$ & $0.745^{\mathrm{x}}$ & $82.1^{\mathrm{x}}$ & $41.7^{\mathrm{x}}$ \\
Gilt & $2.0^{\mathrm{y}}$ & $0.749^{\mathrm{y}}$ & $83.0^{\mathrm{y}}$ & $44.5^{\mathrm{y}}$ \\
SED $^{\mathrm{c}}$ & 0.03 & 0.001 & 0.1 & 0.3 \\
\hline
\end{tabular}

${ }^{\mathrm{a}} \mathrm{BF}=$ backfat measured off the midline at the 10th rib of a chilled, ribbed carcass, $\mathrm{DR}=$ dressing percent, $\mathrm{LEN}=$ carcass length, and LMA = 10th-rib LM area.

${ }^{\mathrm{b}}$ Differences among least squares means estimate half the additive genetic plus all the maternal effect. $\mathrm{ADSG}=$ American Diamond Swine Genetics (Prairie City, IA), DB = Danbred USA (Seward, NE), DK $=$ Monsanto Choice Genetics DK44 (St. Louis, MO), GPK347 = Monsanto Choice Genetics GPK347, NH = Newsham Hybrids (Colorado Springs, CO), and NSR = National Swine Registry (West Lafayette, IN; Landrace $\times$ Large White).

${ }^{\mathrm{c}} \mathrm{SED}=$ standard error of the difference among least squares means.

$\mathrm{x}, \mathrm{y}, \mathrm{z}$ Means among maternal lines or between sexes, within columns, that do not have a common superscript differ, $P<0.05$.

\section{Discussion}

Differences between gilts and barrows existed for all traits and agree with previous reports of sex differences (Larzul et al., 1997; Tischendorf et al., 2002; Berg et al., 2003). Important genetic differences in growth and carcass traits existed among commercially available maternal lines. Lines evaluated were, primarily, Large White and Landrace crosses and differed because of the unique selection history of these lines by breeding organizations. Differences among lines are due to founder effects, different selection protocols within organizations, and random genetic drift. Selection indexes that breeding organizations use to develop maternal lines commonly include BF, LMA, and ADG. Different selection strategies applied to lines with a common origin could, in time, result in a change in ranking of maternal lines for individual traits. However, several generations of intense selection for different objectives, such as growth and carcass traits, would be required to create the observed differences among lines. The selection background for parental lines of these maternal lines is known only for the NE Index line that made up half of the GPK347 female. The NE Index line was formed by crossing Landrace and Large White in 1979 and selected only for increased litter size (Johnson et al., 1999). This selection history likely explains why this line had slower growth and fatter carcasses than most other lines.

\section{Implications}

Significant differences among commercially available dam lines exist for growth, backfat, dressing percent, carcass length, and longissimus muscle area. These traits are economically important and should be considered when choosing maternal lines for commercial production. Progeny of the GPK347 line, previously identified as having superior reproductive performance, grew more slowly than other lines and were among those with the least longissimus muscle area. Failure to consider differences among commercially available maternal lines for growth and carcass traits may hurt profitability. Values of these traits relative to reproductive traits should be considered in integrated economic analyses for specific markets to properly evaluate lines.

\section{Literature Cited}

Baas, T. J., R. N. Goodwin, L. L. Christian, R. K. Johnson, O. W. Robison, J. W. Mabry, K. Clark, M. Tokach, S. Henry, and P. J. Berger. 2003. Design and standards for genetic evaluation of swine seedstock populations. J. Anim. Sci. 81:2409-2418.

Bennett, G. L., M. W. Tess. G. E. Dickerson, and R. K. Johnson. 1983. Simulation and crossbreeding effects on costs of production. J. Anim. Sci. 56: 801-813.

Berg, E. P., E. L. McFadin, K. R. Maddock, R. N. Goodwin, T. J. Baas, and D. H. Keisler. 2003. Serum concentrations of leptin in six genetic lines of swine and relationship with growth and carcass characteristics. J. Anim. Sci. 81:167-171.

Hayter, A. J. 1984. Proof of the conjecture that the Tukey-Kramer method is conservative. The Annals of Statistics. 12:61-75.

Johnson, R. K., Nielsen, M. K. and D. A. Casey. 1999. Responses in ovulation rate, embryonal survival, and litter traits in swine to 14 generations of selection to increase litter size. J. Anim. Sci. 77:541-557.

Kuhlers, D. L., S. B. Jungst, and J. A. Little. 1985. Comparisons of specific crosses from Duroc, Hampshire, and Spot backcross sows. J. Anim. Sci. 60:603-607.

Larzul, C., L. Lefaucheur, P. Ecolan, J. Gogue, A. Talmant, P. Sellier, P. Le Roy, and G. Monin. 1997. Phenotypic and genetic parameters for longissimus muscle fiber characteristics in relation to growth, carcass, and meat quality traits in Large White pigs. J. Anim. Sci. 75:3126-3137.

McLaren, D. G., D. S. Buchanan, and R. K. Johnson. 1987. Growth performance for four breeds of swine: Crossbred females and purebred and crossbred boars. J. Anim. Sci. 64:99-108.

Moeller, S. J., R. N. Goodwin, R. K. Johnson, J. W. Mabry, T. J. Baas, and O. W. Robison. 2004. The National Pork Producers Council Maternal Line National Genetic Evaluation Program: A comparison of six maternal genetic lines for female productivity measures over four parities. J. Anim Sci. 82:41-53.

Tischendorf, F., F. Schöne, U. Kirchheim, and G. Jahreis. 2002. Influence of conjugated linoleic acid mixture on growth, organ, weights, carcass traits and meat quality in growing pigs. J. Anim. Physiol. 86:117-128.

Wilson, E. R., and R. K. Johnson. 1981. Comparison of three-breed and backcross swine for litter productivity and postweaning performance. J. Anim. Sci. 52:18-25. 